\title{
The Impact of the Activity Based Costing System (A.B.C.) in the Pricing of Services Banks in the Jordanian commercial Banks: A Field Study
}

\author{
Atef Aqeel Al-Bawab ${ }^{1}$, Hani Al-Rawashdeh ${ }^{1}$ \\ ${ }^{1}$ Irbid National University, Irbid, Jordan \\ Correspondence: Atef Aqeel Al-Bawab, Irbid National University, Irbid, Jordan. Tel: 00962777326901. \\ E-mail: atefbawab@yahoo.com
}

Received: February 14, 2016

Accepted: February 18, 2016

Online Published: March 5, 2016

doi:10.5539/ibr.v9n4p1

URL: http://dx.doi.org/10.5539/ibr.v9n4p1

\begin{abstract}
This study aims to identify the impact of the application of Activity Based Costing (A.B.C.) in the pricing of banking services in the Jordanian commercial banks, and to achieve the objectives of this study a questionnaire was designed and analyzed by (SPSS) program, was used descriptive statistics mean, standard deviation and percentages, as well as use the T-test to test the hypothesis of the study. One of the most important results of the study that the (A.B.C.) system helps in pricing and in compute cost of the banks services.

The study recommended that it has to update the hardware and software to suit the (A.B.C.) system, as well as the need to train workers in the Jordanian commercial banks in supervisory positions for the application and implementation of the (A.B.C.) system to help in operations costing and pricing of banking services.
\end{abstract}

Keywords: cost accounting, (A.B.C.) system, commercial banks

\section{Introduction}

The banking sector of more-for-profit sectors, which actually made huge profits in most of the world, so this sector is one of the main parts of the national economy, banks have competed to attract the largest amount of customers through new banking products, and raising the quality of existing banking services level, the price of service was the main driver in influencing customer behavior.

The banks are an important part of the national economy in all countries of the world, therefore it is necessary to keep on this sector and on its profitability, hence the need to research and development in all possible to develop performance and supports their competitiveness especially in light of economic changes the global financial crises such as the financial crisis that occurred in 2008.

"In today's competitive business environment, all companies including commercial banks try very hard to gain competitive advantage over their rivals by improving their infrastructures (Amiri Aghdaie et al., 2012), adopting new technologies (Riasi and Amiri Aghdaie, 2013; Riasi, 2015), using more efficient marketing strategies (Riasi and Pourmiri, 2015; Riasi, 2015) and educating their employees and managers (Riasi and Asadzadeh, 2015, 2016).”

\section{Study Problem}

Many researchers believe that the A.B.C. (Activity Based Costing) system is not applicable, but some studies have shown that the application of the system in service institutions, including the banking sector, such as study (Johmani and Al-Omari, 2003), and thus it is possible to determine the cost all accurately service, and take the rational management decisions for the purposes of pricing or create new services, or cancel some services. And it can be asked the following question:

Does the (A.B.C.) system help in the pricing and measurement of the cost banking service in the Jordanian commercial banks?

\section{Study Significance}

The banking sector has always been one of the important sectors in the economies of any country in the world, because of its clear effect on the national economy. It is therefore necessary to conduct research and studies in several influential aspects in how to maintain on the continuity of the sector. Therefore, the importance of the study lies in the revision of 
the banking services prices, not in the possibility of the application system (ABC), which contributes in the improvement of the banks performance and maximize profitability according to accurate and reasonable information.

\section{Study Objectives}

This study aimed to focus on the re-pricing of banking services in the light of the application (A.B.C.) system in the Jordanian commercial banks, and to achieve this goal has been formulated objectives of the study, including the following:

1. Knowledge for the extent of participate for the (A.B.C.) system in the pricing of banking services in the Jordanian commercial banks.

2. Determine the accuracy provided by the application (A.B.C.) system in the calculation of the costs of banking services in the Jordanian commercial banks.

\section{Literature Review}

There are many studies that have addressed the issue of the application (A.B.C.) system, as the following:

Elhamma and Moalla study 2015, entitled "Impact of uncertainty and decentralization on activity- based costing use".

The aim of this paper is to explore the impact of environmental and organizational factors on activity-based costing (ABC) use. These variables are studied respectively through the perceived environmental uncertainty, and the organizational structure represented by both horizontal and vertical decentralization.

Data were collected from 62 Moroccan firms, operating in different sectors, via a questionnaire survey. The findings indicated that $\mathrm{ABC}$ use is not associated with perceived environmental uncertainty and horizontal decentralization. However, firms with a high degree of vertical decentralization use more $\mathrm{ABC}$ than those with a centralized vertical structure $(\mathrm{p}<10 \%)$.

This research adds to general knowledge and offers insights into management accounting since the study is conducted in a developing country that has specific environmental and organizational characteristics. Previous research has studied perceived environmental uncertainty in other contexts of innovations. In our paper, we investigate the case of $\mathrm{ABC}$ and we analysis decentralization with both horizontal and vertical dimensions.

Zu'rob, study 2012, entitled "The importance of using target cost at improving the efficiency of banking services pricing: An Empirical Study on the banks in the Gaza Strip".

The study aimed to show of the importance of using targeted cost approach at improving the efficiency of banking service pricing, and whether there is a possibility for the application of this approach in banks in the Gaza Strip, and to achieve the goal of the study was the use of deductive approach through a questionnaire designed to collect and analyze data statistically. The study concluded that many of the results was the most important: it can be applied to the target in the banks cost approach with the presence of some obstacles, including: lack of effective my costs system in the bank, as the study showed that the bank management is well aware of the benefits diverse achieved through the application of this approach, The study recommended a number of recommendations, including: the need to work hard to move towards the implementation of the target cost approach.

\section{Al D'ari study 2007 entitled "Activity - Based Costing\& Customer profitability".}

This study aimed to apply the costing system (A.B.C.) in the Yemeni banks as well as the possibility of using this system to determine customer profitability and determining the features of this system.

The study found that the application of the system of (ABC) in Saba Islamic Bank help in customer profitability analysis of the bank and make able to manage the relationship with its customers more efficiently, and raise marketing Bank and competitiveness, as the application of this system has helped to raise the bank's efficiency in resources management and its uses.

The study recommended the need for the banks' processing of the basic requirements for the application of this system such as the preparation of organizational structures, and administrative regulations, the manner in which helps to divide the main activities and to facilitate sub-application of this system, in addition to the need to develop information systems.

Hillis study 2007, entitled "The costs of the activities system as the basis for measuring the cost of educational services to universities."

This study aims mainly to the possibility of the use of (A.B.C.) system in the field of measurement and rationalize the cost of educational services, and provide the necessary information in the field of rationalization of administrative decisions, and determine the prices of those services in the universities by objectively. To achieve the objectives of the 
study were used inductive approach by reviewing the verses, as well as deductive approach has been used to study the possibility of using the costs of activities to provide the necessary system to address shortcomings and devise possible to measure two aspects of development and the rationalization of the cost of educational services data. The study concluded that the results of several of them: he can overcome the problems associated with the use of the traditional allocation and distribution of indirect costs roads, as well as the possibility of overcoming the capitalist loading problem.

\section{Radwan study 2006, "the application of costing system in the commercial banks operating in Yemen."}

This study aimed to highlight the importance of applying the (A.B.C.) system in the commercial banks of Yemen sector and knowledge of the difficulties that hinder the implementation of this system, in addition to knowing the extent of awareness of commercial banks in the Republic of Yemen, the importance of costs in the banking system.

This study found that a large proportion of commercial banks in Yemen do not apply costing system, as well as the lack of awareness among commercial banks in Yemen, the importance of the application of cost accounting system, and the banking pricing with a large proportion of commercial banks in Yemen are without foundation based on cost systems . The study recommended a number of recommendations, including the need to establish timetables for the implementation of system costs in the Yemeni banking sector.

\section{Abdal Ghani study 2005, entitled "The possibility of applying the (A.B.C.) System in the Jordanian services sector."}

This study aimed to explore the possibility of the application(A.B.C.) System in the Jordanian services sector, specifically in the university educational institutions, also aimed to identify the most important obstacles that could face the application of this system and the benefits that can be achieved.

This study found a set of results the most important potential application A.B.C. system through the elements which application in the Jordanian university educational institutions, as well as the absence of any limitations or problems in the implementation of this system in the Jordanian university educational institutions with the exception of the unwillingness of the management of the existing system change has the high costs, and the difficulty of determining time spent on each activity of the employee, also found that the system will achieve the benefits of the institution applied to them.

This study recommended to encourage educational institutions to apply the activities based cost system.

\section{Johmani and Omari study 2003, entitled "Application cost accounting systems commercial banks operating in Jordan: An Empirical Study."}

The study aimed to highlight the importance of the application in cost accounting systems in commercial banks in Jordan. and their importance in making different decisions, specially decisions of the pricing of services, also aimed to find out the difficulties that prevent the application of cost accounting in the Jordanian commercial banks and supplying them with qualified and trained talent to run those systems and realize the benefit systems of them, and it was the results of the study are that the majority of commercial banks do not create a section or unit costs, and that the banks use different methods to allocate costs, the study recommended that the attention of the bank's decision to banking service pricing.

\subsection{What Distinguishes This Study?}

Previous studies mainly focused on the applicability of the (A.B.C.) system in the service and banking sector, and most of the results of the studies show that the system can be applied, but the current study focused on the re-pricing of the banking services pricing in various types of process, in order to work on identifying the exact price and reasonable profit margin in the Jordanian commercial banks sector.

\section{Hypothesis Study}

HO: The (A.B.C.) system does not help in pricing and measuring of the cost of banking services in the Jordanian commercial banks.

\subsection{Methodology Study}

To achieve the objectives of the study, the study relied on two approaches, namely:

First, the descriptive approach is concerned with the theoretical side, through reference to books, research, and theses.

Second, the analytical approach is concerned with the field side, through a questionnaire designed to gather data on the study population.

\section{The Theoretical Framework: Cost Accounting and (A.B.C.) System}




\subsection{The Concept of Cost Accounting}

Cost accounting is a branch of accounting, the need of the cost accounting started when the financial accounting failed to provide detailed information for the management established to confront many of the problems related to adjusting the control and evaluation of performance and pricing of products. The period from 1880 till 1900 represent the golden age of cost accounting, where it established the basic cost accounting systems (commands costs system and stages costs system) (Iryani, 2007, p. 6).

Cost accounting can be defined as: The sacrifices or amounts which the company pay in order to obtain a good or service, or to achieve a particular goal (Abu Nassar 0.2014 p. 23).

\subsection{The Objectives of Cost Accounting}

The objectives of cost accounting following: (Annati 0.2001, p. 17).

1. Measure the unit cost of producing or service sold per element of direct and indirect cost.

2. Make control on the cost elements through do system for the cost in order to reach optimal use of the various factors of production design.

3. Provide management with appropriate information to take the management decisions on the short-term such as cancel of a good or provide a service or continue in their production, also help to take long-term decisions, such as investing in new projects.

4. Assistance in preparing budgets through the study of the behavior of costs and predictable.

5. Assist in pricing policies for products or services fee, which takes into account when determining the price of a product or service the cost of that product and the margin and the intensity of competition in the market profit target and the desire to increase market share or control of the market and the extent of the existence of price algebraic by the government.

\subsection{The Cost Systems}

The cost accounting helps to measure the cost of the production by use the cost systems, in this part we will show the cost systems following: the cost system of the productivity commands.

\subsubsection{The Cost System of the Productivity Commands}

It depends on the customers orders who determine the specifications of goods to be produced or to be provided service orders, and often are those different specifications in terms of type, size, shape and therefore the cost of each of them be different from the other. One of the main features of this system include (Al-Tikriti, 2008, p. 23):

1. The nature of the production is diversified and has a specification defined by customers as each production is different from the other.

2. Each order is an independent production from other

3. production is not for the purpose of storage.

4. Determine the cost of the command is not related by the period, but related by the finish of the production.

5. Facilitate the process of the distinction between direct and indirect expenses charged on the operating commands various.

6. Possibility of using the cost of production orders that have been completed in the planning and estimating the cost of similar orders received by the facility in the future.

\subsubsection{The Cost System of the Productivity Stages}

It uses in the industrial companies which have continuous production system, and we mean by continuous that does not stop the productive activity from the management of production departments, the characteristics of this system are as follows (Faker and Al-Duliami, 2003, p 111):

1. The production is large sizes and continuous, also can be equal to production with production capacity available.

2. Divide the technological process for the production of an independent consecutive operations (stages) the production of the first phase is the raw material for the second phase and the production of the second phase of raw material for the third phase and so on.

3. The production may be in the form of a single line flow to reach the final stage, or in the form of parallel lines.

4. The number of stages of the facility to another may differ depending on the nature of the product. 


\subsection{The Problems of the Traditional Systems}

The traditional systems are designed to cope with the circumstances that accompanied its creation and evolution, and in recent years have increased problems resulting from the traditional systems as a result of the tremendous changes in the field of production and services, technological change, and can be summarized as the most important problems in the following points: (al-Tikriti, 2008, p. 156):

1. The traditional systems are no longer able to control the processes and accurately measuring the cost of production because of the distractions on the overall assembly sections and not restrict the products that caused the distractions.

2. The traditional systems rely on some measures associated with size (such as direct labor hours) as a base for distribution of indirect costs, leading to a private cost deformation in the event of a difference productivity sizes of products and the diversity of the degree of complexity of the products.

3. The inclusion of indirect costs to the stocks will encourage the administration to increase inventory and not be reduced and this is not commensurate with the adoption of modern systems such as manufacturing production in time (JIT).

4. The traditional systems focused on determining the amount of costs and focus on reducing costs because they do not determine the activities and costs that do not add value to the product.

\subsection{Emergence and Development the Activities Based on Costing System (ABC)}

Many studies indicated on the basis of the concepts of activity, but the prominent role in this area back in the late eighties through the writings of (Cooper and Kaplan, 1998). The (A.B.C.) system passed by several Phases:

Phase I: Activity Management (Activity Management AM) this stage has focused on the concept of the value chain more than accounting and financial analysis, and aimed to achieve the following:

1. Discovery and the exclusion of activities that do not add value to the series, such as the use of the immediate production system (JIT).

2. Improve and promote activities that add value, by improving the quality and speed of response to customer requests.

Phase II: Activity Cost Accounting (A.C.A.), came this stage to confirm that all costs have been reduced or minimized through:

1. Identify the causes of cost and linked activities.

2. Trace interactions activities with other activities.

Phase III: Activity-Based Costing (A.B.C.)

The identification of activities is the basis for this system, and the activity is an event or specific business unit purpose such as product design, preparation machinery, operating machinery, product distribution. (Horngren, 2006, p 144).

7.6 The Factors That Help to Shift towards (A.B.C.) System

There are many factors helped to shift towards (A.B.C.) System as following: (Cooper, 1998.p196):

1. Availability of an accounting system can provide the necessary and detailed data for the purposes of identifying and measuring the relationship between the cost and drive it.

2. Change in the industrial environment in automation technology which help increasing of the indirect cost.

3. Diversity of products.

4. Increase the number of the sections production support.

5. Heightened market competition that leading to a trend to reduce the cost and improve the quality of products.

6. Management directions to the continuous development and adapt to the new requirements of the market.

7. The difference in the size of the quantities produced.

8. The common costs represent a large percentage of the total costs.

9. The dip in the pricing of the competing products in the market.

10. Inability to interpret the percentage of the profit derived from the certain pro

\section{Statistical Analysis and Testing the Study Hypothesis}

\subsection{The Population of the Study}


The study population consisted of workers in the Jordanian commercial banks in supervisory jobs, of which there were (13) banks until the end of 2014, according to the annual report of the Central Bank of Jordan. It has been selected a random sample of this community. And the table 1 shows that.

Table 1. A table shows the population of the study

\begin{tabular}{|c|c|c|c|c|c|}
\hline No. & Name of Bank & $\begin{array}{l}\text { Established } \\
\text { years }\end{array}$ & $\begin{array}{l}\text { No. Branches in } \\
\text { inside }\end{array}$ & No. of Offices & $\begin{array}{l}\text { No. Branches in } \\
\text { outside }\end{array}$ \\
\hline 1. & Arab Bank & 1930 & 74 & - & 112 \\
\hline 2. & Jordan Ahli Bank & 1956 & 55 & 1 & 6 \\
\hline 3. & Bank of Jordan & 1960 & 69 & 13 & 15 \\
\hline 4. & Cairo Amman Bank & 1960 & 69 & 14 & 19 \\
\hline 5. & $\begin{array}{c}\text { Housing Bank for Trade and } \\
\text { Finance }\end{array}$ & 1974 & 112 & 11 & 14 \\
\hline 6. & Jordan Kuwait Bank & 1977 & 56 & 1 & 2 \\
\hline 7. & Jordan Commercial Bank & 1978 & 28 & 2 & 4 \\
\hline 8. & $\begin{array}{c}\text { Arab Jordan Investment } \\
\text { Bank }\end{array}$ & 1978 & 19 & 14 & 1 \\
\hline 9. & $\begin{array}{l}\text { Arab Banking Corporation } \\
\text { (ABC) (Jordan) }\end{array}$ & 1989 & 27 & - & - \\
\hline 10. & Invest Bank & 1989 & 10 & - & - \\
\hline 11. & Bank Aletihad & .1991 & 37 & - & 1 \\
\hline 12. & $\begin{array}{l}\text { Society General Bank - } \\
\text { Jordan }\end{array}$ & 1993 & 16 & - & - \\
\hline 13. & Capital Bank of Jodan & 1996 & 12 & - & - \\
\hline
\end{tabular}

Source: The annual report of the Central Bank of Jordan, 2014.

www.cbj.gov.jo

\subsection{Statistical Methods Used}

It was used the following statistical methods

1. Cronbach's alpha test to test the stability of the tool study.

2. Percentages and frequencies to test the demographic characteristics for the sample study.

3. The means and standard deviations to test the sample study about the opinions of the paragraphs of the questionnaire.

4. Make T- Test to test the hypothesis of the study.

This was done through the Statistical Package for Social Sciences (SPSS) program.

\subsection{Stability of the Questionnaire}

Shown in Table 2 Cronbach's alpha coefficient, which indicates the existence of reasonable stability and statistically significant coefficient, where the reliability coefficient was greater than 0.60 and thus become paragraphs are valid for analysis and application.

Table 2. The value of Cronbach's alpha coefficient for each paragraphs of questionnaire

\begin{tabular}{lcc}
\hline The description & No. of paragraphs & Cronbach's alpha coefficient \\
\hline The application (ABC) system helps in & & \\
pricing and in the measurement of the & 16 & 0.813 \\
cost of banking services in the & & \\
Jordanian commercial banks.
\end{tabular}

\section{Sample Characteristics}

It is an analysis of the demographic characteristics of the study sample as shown in Table 3. 
Table 3. A table showing analysis of the demographic characteristics of the study sample.

\begin{tabular}{|c|c|c|c|}
\hline Description & Group & $\begin{array}{l}\text { Frequencies } \\
\mathrm{No}_{\mathrm{s}} \text {. }\end{array}$ & $\begin{array}{l}\text { Percentages } \\
\%\end{array}$ \\
\hline \multirow{5}{*}{ Job } & Head of Department & 35 & 62.5 \\
\hline & Supervisor & 11 & 19.5 \\
\hline & Manager or Vice manager & 9 & 16.0 \\
\hline & High Management & 1 & 02.0 \\
\hline & Total & 56 & $\% 100$ \\
\hline \multirow{5}{*}{ Qualification } & Less Than Bachelor & 6 & 10.6 \\
\hline & Bachelor & 44 & 78.5 \\
\hline & Master & 5 & 8.9 \\
\hline & $\mathrm{Ph} . \mathrm{D}$ & 1 & 02.0 \\
\hline & Total & 56 & $\% 100$ \\
\hline \multirow{5}{*}{ Specialization } & Accounting & 26 & 46.3 \\
\hline & Business Administration & 8 & 14.1 \\
\hline & Finance and Banking Science & 15 & 27.0 \\
\hline & Other & 7 & 12.6 \\
\hline & Total & 56 & $\% 100$ \\
\hline \multirow{5}{*}{ Years of Experience } & Less than 5 years & 11 & 19.6 \\
\hline & From $6-10$ years & 35 & 62.5 \\
\hline & From $11-15$ years & 8 & 14.3 \\
\hline & More than 16 years & 2 & 3.6 \\
\hline & Total & 56 & $\% 100$ \\
\hline \multirow{5}{*}{ Age } & Less than 30 years & 14 & 25.0 \\
\hline & From 31 - 40 years & 35 & 62.5 \\
\hline & From $41-50$ years & 5 & 9.0 \\
\hline & More than 51 years & 2 & 3.5 \\
\hline & Total & 56 & $\% 100$ \\
\hline
\end{tabular}

The results showed with respect to functional level that $62.5 \%$ of the sample of department heads and supervisors $19.5 \%, 16 \%$ and departments managers, and thus understand the direct officials to work in automated systems and banks involved in the subject of study, giving the correct answers to questions. With regard to scientific qualification results show that $78.5 \%$ of bachelor's campaign and this gives credibility in the results, with regard to the levels of specialized The results show that $46.3 \%$ of respondents in the field of accounting and $14.1 \%$ in the field of management, and $27 \%$ in the field of Banking, which means that the respondents have a clear idea on the subject of the study, with regard to the level of expertise of the sample, we find that $62.5 \%$ of the sample are the owners of expertise that fall within the category (6-10 years), and this assures us that most of the sample surveyed have experience in the field The banking index also enhance the credibility of the data, with regard to the age level of the majority of the sample was at the age group (31-40), they have accounted for $62.5 \%$, which confirms that the sample may have been selected at random, honest and valid analysis.

\subsection{Analyze and Discuss the Results}

Has been relying on the Likert scale in the analysis of the views of respondents so that the distribution of scores on the answers as in the Table 4 following:

Table 4. A table showing the degrees of on a scale Likert

\begin{tabular}{|c|c|c|c|c|c|}
\hline Paragraph & Strong agree & Agree & Neutral & Disagree & Strong disagree \\
\hline & 5 Degrees & 4 Degrees & 3 Degrees & 2 Degrees & 1 Degrees \\
\hline
\end{tabular}

The table 5 shows the results of the statistical analysis of the views of a sample study to the mean and the standard division of the paragraphs that the application based on the (ABC) system to help in pricing and in the measurement of the cost of banking services in the Jordanian commercial banks accuracy. So that the paragraph be positive and approved by the respondents if the mean is greater than (3) If the mean of less than (3), it means that the answers respondents will be negative and tend to agree, and are the sample views in paragraph neutral when be the arithmetic mean value (3) and standard deviations large and abnormal. The following is a presentation and analysis of results.

Table 5 shows the views of the sample study about the (A.B.C.) system which help in pricing and in the measurement of the cost of banking services in the Jordanian commercial banks accuracy. 
Table 5. A table showing the views of the sample study about the (A.B.C.) system

\begin{tabular}{|c|c|c|c|c|}
\hline No. & Paragraph & Mean & $\begin{array}{l}\text { Standard } \\
\text { Deviation }\end{array}$ & Result \\
\hline 1 & $\begin{array}{l}\text { The (A.B.C.) system helps the departments when pricing the } \\
\text { banking products. }\end{array}$ & 4.33 & .577 & agree \\
\hline 2 & $\begin{array}{l}\text { After understand the (A.B.C.) system some banking services need } \\
\text { to re-pricing based on the study of the real cost. }\end{array}$ & 4.14 & .689 & agree \\
\hline 3 & $\begin{array}{l}\text { After understand the (A.B.C.) system, the bank put the price for } \\
\text { the banking products based on prevailing prices in the banking } \\
\text { market. }\end{array}$ & 3.76 & .747 & agree \\
\hline 4 & $\begin{array}{l}\text { The costing system currently followed is not appropriate to } \\
\text { calculate the cost of banking services. }\end{array}$ & 4.04 & .755 & agree \\
\hline 5 & $\begin{array}{l}\text { After understand the (A.B.C.) system there is a need to re-pricing } \\
\text { of banking services. }\end{array}$ & 3.60 & .761 & agree \\
\hline 6 & $\begin{array}{l}\text { The (A.B.C.) system take cost of the activities into account which } \\
\text { mainly contribute in the cost of services such as high management } \\
\text { and the financial management. }\end{array}$ & 3.91 & .770 & agree \\
\hline 7 & $\begin{array}{l}\text { The (A.B.C.) system take cost of inflation factors in the pricing of } \\
\text { banking service. }\end{array}$ & 3.76 & .812 & agree \\
\hline 8 & $\begin{array}{l}\text { The (A.B.C.) system take cost of the computer system in account } \\
\text { when the banking service pricing. }\end{array}$ & 4.20 & .815 & agree \\
\hline 9 & $\begin{array}{l}\text { The outputs of the (A.B.C.) system help In competitiveness } \\
\text { through the pricing of banking services. }\end{array}$ & 3.95 & .856 & agree \\
\hline 10 & The (A.B.C.) system compute the banking service accurately. & 3.53 & .966 & agree \\
\hline 11 & $\begin{array}{l}\text { The actual cost is considered mainly in banking service pricing } \\
\text { process. }\end{array}$ & 3.92 & .364 & agree \\
\hline 12 & $\begin{array}{l}\text { The (A.B.C.) system Contributes in pricing of the banking } \\
\text { services conveniently. }\end{array}$ & 3.65 & 0.814 & agree \\
\hline 13 & $\begin{array}{l}\text { The (A.B.C.) system needs to development in the current } \\
\text { automated system. }\end{array}$ & 4.01 & 0.633 & agree \\
\hline 14 & $\begin{array}{l}\text { The (A.B.C.) system needs to replace the current automated } \\
\text { system to be most suitable system. }\end{array}$ & 4.23 & 0.714 & agree \\
\hline 15 & $\begin{array}{l}\text { The (A.B.C.) system needs to significant costs in equipment to } \\
\text { computerized systems. }\end{array}$ & 4.22 & 0.766 & agree \\
\hline 16 & $\begin{array}{l}\text { The (A.B.C.) system works to review the prices of banking } \\
\text { services from one period to another. }\end{array}$ & 3.69 & 0.499 & agree \\
\hline
\end{tabular}

We find in the table 5 that the general trend of views tend to agree with evidence that the value of the mean of the vertebrae was the largest class (3) in all the paragraphs, which indicates that the (A.B.C.) system has a role in the banking pricing In calculating the costs accuracy, and this is what enhances their confidence and conviction respondents (A.B.C.) system and its ability to correct the deformity in the cost of banking services which result in deformation of the pricing process.

\subsection{Test of the Study Hypothesis}

Test was used is a (One-Sample T- test) to analyze and test the study hypothesis, which are rejected hypothesis nihilism when the mean value is greater than the center-premise (3), and that the test T calculated value is large and positive, and the level of significance test is less confidence level of 0.05 , the following table (6) introduce us to the results of statistical analysis to test this hypothesis.

Table 6. as a result of the study hypothesis test

\begin{tabular}{lccccc}
\hline Hypothesis. & Mean & St. Division & T - test & $\begin{array}{c}\text { Confidence } \\
\text { level }\end{array}$ & Result \\
\hline $\begin{array}{l}\text { HO: The (A.B.C.) system does not help in pricing and } \\
\text { measuring of the cost of banking services in the }\end{array}$ & 3.92 & 0.364 & 23.073 & 0.000 & rejected \\
Jordanian commercial banks.
\end{tabular}

Table 6 show that the arithmetic mean value was greater than the mean premise (3), where its value amounted to 3.92 and a standard deviation of 0.364 , and since the test $\mathrm{T}$ calculated value was large and positive in terms amounted to 23.073, and the level of significance of this test less the level of confidence 0.05 , reaching 0.00 , it means the presence of significant statistical significant differences between the arithmetic mean calculated from the sample and the center-premise, so it is rejected hypothesis nihilism and acceptance of alternative hypothesis contrary to them, that is based on the activities costing system helps in banking services pricing in accuracy calculating the costs of banking services in the Jordanian commercial banks. 


\section{Conclusions and Recommendations}

\subsection{Conclusions}

1. The current cost system of banking service) is inappropriate and inaccurate.

2. The adoption of (A.B.C.) system helps in calculating the costs of banking services in the Jordanian commercial banks by accuracy.

3. The adoption of (A.B.C.) system helps in the pricing of banking services in the Jordanian commercial banks.

4. The (A.B.C.) system needs to large costs in equipment as personnel training programs in the Jordanian commercial banks.

\subsection{Recommendations}

1. The need to leave the current costs systems and a shift to (A.B.C.) systems after a cost-benefit analysis.

2. The need to apply your document on the (A.B.C.) systems because of its from the role of the in the calculation of banking services the costs of accuracy which contributes to in banking services the pricing of in a more accuracy in the Jordanian commercial banks.

3. The need to update hardware and software to suit the (A.B.C.) systems.

4. the need to train workers in the Jordanian commercial banks in supervisory positions for the application and implementation the (A.B.C.) systems in the calculation of the cost and pricing of banking services.

\section{References}

Abdal, G. A. (2005). The possibility of applying the (A.B.C.) System in the Jordanian services sector, Ph.D thesis, The Arab Academy for Banking and Financial Sciences, Amman, Jordan.

Al-D'ari, A. (2007). Activity-Based Costing\& Customer profitability, Applied research Masters thesis, the HAGUE University, Netherlands.

Al-Tikriti, E. (2008). Advance Cost Accounting, (Modern Issues), $2^{\text {nd }}$ Issue, Dar Al-Hamed for Publishing and Distributing, Amman, Jordan.

Amiri, A. S. F., Seidi, M., \& Riasi, A. (2012). Identifying the Barriers to Iran's Saffron Export by Using Porter's Diamond Model. International Journal of Marketing Studies, 4(5), 129-138. http://dx.doi.org/10.5539/ijms.v4n5p129

Annatii, R. (2001). Cost Accounting (Conceptual ... Principles ... Applications), $2^{\text {nd }}$ Issue, Dar Al-safa' for Publishing and Distributing, Amman, Jordan.

Annual Report for Central Bank of Jordan, (2014). www.cbj.gov.jo

Cooper, R. K., \& Robert, S. (1998). The Design Of Cost Management Systems: Text And Readings, New Jersey, prentice Hall.

Elhamma, M. A., \& Hanen, (2015). Impact of uncertainty and decentralization on activity- based costing use, International Journal of Accounting and Economics Studies, 3(2), 148-155 http://dx.doi.org/10.14419/ijaes.v3i2.4817

Faker, Al-Duliami, N., \& Kalil, (2003). Industrial Cost Accounting - Part 2, Al-Dar Al-Ulmia Al-Duwlia for Publishing and Distributing, Amman, Jordan.

Hillis, S. A. (2007). The costs of the activities system as the basis for measuring the cost of educational services to universities, The Journal of the Islamic university (humanities Studies Series), Islamic University, 15(1), 211-238.

Horngren, C., Datar, S., \& Foster, G. (2006). Cost Accounting (A managerial Emphasis), $12^{\text {th }}$ Ed., prentice Hall Internationl, New Jersy.

Iryani, M. (2007). The Practical and Theoretical framework for The Cost Accounting, $2^{\text {nd }}$ Issue, Dar Alkutub, San'a, Yemen.

Ittner, et al (2002). The Association between Activity-based Costing and Manufacturing Performance, Journal of Accounting Research, 40(3), June. http://dx.doi.org/10.1111/1475-679X.00068

Johmani, O., \& Ahmad, O. (2003). Application cost accounting systems in commercial banks operating in Jordan: An Empirical Study. Al-Yarmuk researches Journal, Yarmuk University, Irbid, 19(1).

Radwan, A. (2006). The application of costing system in the commercial banks operating in Yemen, Master Thesis, Administrative and Humanities Sciences College, Science and Technology University, Sana'a, Yemen. 
Riasi, A. (2015). Barriers to international supply chain management in Iranian flower industry. Management Science Letters, 5(4), 363-368. http://dx.doi.org/10.5267/j.msl.2015.2.005

Riasi, A. (2015). Competitive Advantages of Shadow Banking Industry: An Analysis Using Porter Diamond Model. Business Management and Strategy, 6(2), 15-27. http://dx.doi.org/10.5296/bms.v6i2.8334

Riasi, A., \& Amiri, A. S. F. (2013). Effects of a Hypothetical Iranian Accession to the International Business Research www.ccsenet.org/ibr 4 World Trade Organization on Iran's Flower Industry. Consilience: The Journal of Sustainable Development, 10(1), 99-110.

Riasi, A., \& Asadzadeh, N. (2015). The relationship between principals' reward power and their conflict management styles based on Thomas-Kilmann conflict mode instrument. Management Science Letters, 5(6), 611-618. http://dx.doi.org/10.5267/j.msl.2015.4.004

Riasi, A., \& Asadzadeh, N. (2016). How Coercive and Legitimate Power Relate to Different Conflict Management Styles: A Case Study of Birjand High Schools. Journal of Studies in Education, 6(1), 147-159. http://dx.doi.org/10.5296/jse.v6i1.8946

Riasi, A., \& Pourmiri, S. (2015). Effects of online marketing on Iranian ecotourism industry: Economic, sociological, and cultural aspects. Management Science Letters, 5(10), 915-926. http://dx.doi.org/10.5267/j.msl.2015.8.005

Zu'rob, H. S. (2012). The importance of using target cost at improving the efficiency of banking services pricing: An Empirical Study on the banks in the Gaza Strip. The Journal of the Islamic university for the Economic and Management Studies, 20(1), 229-263.

\section{Copyrights}

Copyright for this article is retained by the author(s), with first publication rights granted to the journal.

This is an open-access article distributed under the terms and conditions of the Creative Commons Attribution license (http://creativecommons.org/licenses/by/3.0/). 